\title{
Toward a more efficient isolation of total RNA from loquat (Eriobotrya japonica Lindl.) tissues
}

\author{
Amparo Martínez-Fuentes, Carlos Mesejo, Manuel Agustí and Carmina Reig ${ }^{\star}$ \\ Instituto Agroforestal Mediterráneo, Universitat Politècnica de València. Cno. Vera s/n. 46022 Valencia, Spain
}

Received 6 July 2014 - Accepted 4 November 2014

\begin{abstract}
Introduction. Loquat (Eriobotrya japonica Lindl.) tissues contain considerable amounts of polyphenolic compounds and polysaccharides which can copurify with RNA. This can render the RNA unsuitable for DNA synthesis and makes the isolation of high quality RNA from loquat tissues particularly difficult. Materials and methods. Total RNA was extracted from leaves, buds and fruit of loquat by adapting the method described by Song et al. in 2011. This involved improvements both to the extraction protocol and RNA purity. Results and discussion. Our modified method resulted in the isolation of high quality RNA with yields 6-20 times higher than that reported for existing methods. We obtained $\mathrm{A}_{260 / 280}$ ratios of 2-2.40 $\mathrm{A}_{260 / 230}$ ratios of 2-2.31 and RNA integrity numbers (RIN) of 8 to 8.3 . The RNA obtained has reached the requested quality for downstream applications such as quantitative real-time polymerase chain reaction (RT-qPCR) experiments.
\end{abstract}

Keywords: Spain / loquat / Eriobotrya japonica / phenolics / RNA extraction

\begin{abstract}
Résumé - Pour une meilleure methode d'extraction de l'ARN des tissus de néflier du Japon (Eriobotrya japonica Lindl.). Introduction. Les tissus du néflier du Japon (Eriobotrya japonica Lindl.) contiennent des quantités considérables de composés phénoliques et des polysaccharides qui accompagnent souvent l'ARN au cours de la purification, le rendant alors impropre à la synthèse d'ADN. Cette caractéristique fait qu'il est particulièrement difficile d'isoler de l'ARN de haute qualité à partir des tissus du bibacier. Matériel et méthodes. L'ARN total a été extrait des feuilles, des bourgeons et de la pulpe des fruits du bibacier à partir de la méthode décrite par Song et al. in 2011. Les améliorations proposées portent à la fois sur le protocole d'extraction et la pureté de l'ARN extrait. Résultats et discussion. Notre méthode modifiée a abouti à l'isolement d'ARN de haute qualité, avec un rendement 6 à 20 fois plus élevé que ceux rapportés précédemment, des rapports $\mathrm{A}_{260 / 280}$ de 2.00-2.40 et des rapports $\mathrm{A}_{260 / 230}$ de 2.00-2.31, et une intégrité de l'ARN (RIN) de 8.00-830. L'ARN ainsi obtenu atteint le niveau requis pour des applications en aval, telles que les expériences de PCR quantitative en temps réel (RT-qPCR).
\end{abstract}

Mots clés : Espagne / bibacier / néflier du Japon / Eriobotrya japonica / composés phénoliques / extraction d'ARN

Abbreviations used: CTAB, cetyltrimethylammonium bromide; PVPP, polyvinyl polypyrrolidone; FW, fresh weight; RT-qPCR, quantitative real-time polymerase chain reaction; RIN, RNA Integrity Number.

\section{Introduction}

Molecular tools are becoming very useful in modern fruit tree research. RNA from common herbaceous model plants like arabidopsis, tobacco, tomato, potato or maize is usually isolated using traditional methods [1]. However, there are many other plant species and especially fruit tree species for which RNA isolation has been particularly difficult. This is the case of loquat, a species richer in polysaccharides, proteins and polyphenolic compounds than other herbaceous $[2,3]$ and

\footnotetext{
^ Corresponding author: mareiva@prv.upv.es
}

even fruit tree species like apple or pear $[4,5]$. These interfering chemicals can cause degradation and low yield of functional RNA through polyphenolic compounds oxidation and co-precipitation with polysaccharides [6] This affects both the quantity and quality of the RNA isolated [7]. This is the case of the protocol described by Song et al. [8] for loquat that, although generally accepted, gives rise to low quantities of low quality RNA.

In this paper we describe modifications made to the protocol described by Song et al. [8] that allows the successful isolation of large quantities of high quality RNA from leaves, buds and fruit pulp of loquat tissues. 


\section{Materials and methods}

\subsection{Plant material}

Leaves, buds and fruits of Eriobotrya japonica cv. Algerie were collected from trees located in a commercial orchard in Callosa d'En Sarrià (Alicante, Spain. 38 $39^{\prime} \mathrm{N}, 00^{\circ} 07^{\prime} \mathrm{W}$ ). Samples were frozen immediately in liquid nitrogen and stored at $-80^{\circ} \mathrm{C}$ until use.

\subsection{Solutions required}

Extraction buffer: 3\% (w/v) CTAB; $100 \mathrm{mM}$ Tris- $\mathrm{HCl}$ (pH 8.0); 1.4 M NaCl; 200 mM EDTA. Mixed and autoclaved before adding Tris-HCl. $\beta$-mercaptoethanol was added to a final concentration of $4 \%(\mathrm{v} / \mathrm{v})$ just before use.

Other solutions: $3 \mathrm{M}$ potassium acetate $(\mathrm{pH} 5.5)$; phenol:chloroform:isoamyl alcohol (25:24:1, v/v); chloroform: isoamyl alcohol $(24: 1, \mathrm{v} / \mathrm{v})$; isopropanol; $70 \%$ ethanol $(\mathrm{v} / \mathrm{v})$; 10 mM Tris- $\mathrm{HCl}$ (pH 7.5); $10 \mathrm{M}$ lithium chloride; RNase free water.

\subsection{RNA extraction protocol}

Frozen material was ground into a fine powder with a precooled mortar and pestle in the presence of liquid nitrogen. A $0.5 \mathrm{~g}$ sample of powder and $400 \mathrm{mg}$ of PVPP were transferred to $30 \mathrm{~mL}$ sterile, disposable, polypropylene, RNase-free centrifuge tubes containing $10 \mathrm{~mL}$ of pre-heated $\left(65^{\circ} \mathrm{C}\right)$ extraction buffer. The tubes were then incubated $25 \mathrm{~min}$ at $65^{\circ} \mathrm{C}$ with occasional shaking.

After adding $1 \mathrm{~mL}$ potassium acetate, samples were incubated $30 \mathrm{~min}$ on ice. Then an equal volume of phenol:chloroform:isoamyl alcohol $(25: 24: 1, \mathrm{v} / \mathrm{v})$ was added to extract the total RNA crude solution. The tubes were then centrifuged $\left(10 \mathrm{~min}, 20,000 \mathrm{~g}, 4{ }^{\circ} \mathrm{C}\right)$ and the supernatants transferred to new sterile tubes, pipetting carefully the aqueous phase and not collecting the white phase formed in the interphase and corresponding to the flocculent material. The phenol:chloroform:isoamyl alcohol extraction was repeated three times. The final supernatants were mixed with 1 volume of chloroform:isoamyl alcohol $(24: 1 \mathrm{v} / \mathrm{v})$ to avoid excessive phenol in the samples. The RNA was recovered by centrifugation (10 $\mathrm{min}, 20,000 \mathrm{~g}, 4{ }^{\circ} \mathrm{C}$ ); 1 volume of cold isopropanol was added to the collected aqueous layer and incubated at $-80^{\circ} \mathrm{C}$ overnight to precipitate total RNA.

After incubation, the tubes were centrifuged $(20 \mathrm{~min}$, $20,000 \mathrm{~g}, 4{ }^{\circ} \mathrm{C}$ ) and the supernatants decanted immediately. The pellets were rinsed with $70 \%$ ethanol $(200-500 \mu \mathrm{L}$ depending on the pellet size) and collected by centrifugation ( $5 \mathrm{~min}, 20,000 \mathrm{~g}, 4^{\circ} \mathrm{C}$ ). They were then air dried, resuspended in $1 \mathrm{~mL}$ Tris- $\mathrm{HCl}$, and transferred to a microtube so as to later repeat precipitation.

Following the extraction, the RNA was precipitated by adding $1 / 4$ volume of $10 \mathrm{M}$ lithium chloride, mixed by inversion and incubated at $-80{ }^{\circ} \mathrm{C}$ for $2-3 \mathrm{~h}$. Nucleic acids were recovered by centrifugation $\left(20 \mathrm{~min}, 20,000 \mathrm{~g}, 4^{\circ} \mathrm{C}\right.$ ), washed with $70 \%$ ethanol, air dried and then dissolved in $100 \mu \mathrm{L}$ RNase free water. Isolated total RNA was purified using the RNeasy ${ }^{\circledR}$ Kits technology from Qiagen ${ }^{\circledR}$. With the RNeasy ${ }^{\circledR}$ procedure, all RNA molecules longer than 200 nucleotides were purified, providing and enriching mRNA since most RNAs $<200$ nucleotides (such as 5.8S rRNA, 5S rRNA, and tRNA, which together comprise $15-20 \%$ of Total RNA) were selectively excluded. The RNeasy ${ }^{\circledR}$ Kits technology combines the selective binding properties of a silica-based membrane with the speed of microspin technology. A specialized highsalt buffer system allows up to $100 \mu \mathrm{g}$ of RNA longer than 200 bases to bind to the RNeasy ${ }^{\circledR}$ silica membrane. Samples were then stored at $-80{ }^{\circ} \mathrm{C}$ until use.

\subsection{Determination of RNA Quality}

The purified RNA was measured by spectrophotometric analysis (ND1000 NanoDrop, Thermo Fisher Scientific, Madrid, Spain). Purity and yield of total RNA isolated were estimated from the absorbance ratios $A_{260 / 230}$ and $A_{260 / 280}$, which are measures of contamination by the polyphenols/carbohydrates and proteins, respectively. Typically $2 \mu \mathrm{L}$ of each sample was used.

The integrity of total RNA was verified by agarose gel electrophoresis, stained ethidium bromide and visualized under UV light. The integrity and quality of purified RNA were both analyzed using an Agilent 2100 Bioanalyzer (Agilent Technologies, http://www.agilent.com/) according to the manufacturer's instructions (RIN values).

\section{Results and discussion}

In recalcitrant fruit tree species, successful results have been reported when using RNA isolation methods [9-11]; however, protocols must be adjusted and optimized for each new plant species being studied [12]. Reports in the literature show that even the simplest modifications can enhance the efficiency of RNA isolation, as they did in our study for loquat tissues. In this case to successfully isolate total RNA from tissues rich in polysaccharides and polyphenolic compounds, it is crucial to prevent the binding of these contaminants to the nucleic acids.

In our study the method described by Song et al. [8] was modified as follows: less than the usual weight of FW $(0.5 \mathrm{~g} \mathrm{FW})$ was used in $10 \mathrm{~mL}$ extraction buffer because larger amounts of loquat tissues made the extracting solution more viscous, gluelike, muddy and unmanageable when pipetting. Larger amounts also resulted in a partially degraded RNA. We reduced the ratio of tissue weight-to-buffer volume from $0.2-0.1$ to 0.05 [11].

The first extraction was performed in a buffer containing 3\% CTAB, $1.4 \mathrm{M} \mathrm{NaCl}, 200 \mathrm{mM}$ EDTA, $100 \mathrm{mM}$ Tris- $\mathrm{HCl}$ and $4 \% \beta$-mercaptoethanol. We increased the $\beta$ mercaptoethanol concentration in the buffer in order to eliminate ribonucleases being released during cell lysis. Numerous disulfide bonds make ribonucleases very stable enzymes, so $\beta$-mercaptoethanol was used to reduce these disulfide bonds 
Table I. The effect of a modified protocol on quality and yield analyses of total RNA isolated from three loquat tissues in comparison with that of Song et al. [8]. Each value is the mean of three replicates.

\begin{tabular}{|c|c|c|c|c|c|}
\hline \multirow{2}{*}{ Isolating method } & \multirow{2}{*}{ Tissue } & \multicolumn{2}{|c|}{ Absorbance ratios } & \multirow{2}{*}{ RIN } & \multirow{2}{*}{$\begin{array}{c}\text { RNA yield } \\
\left(\mu \mathrm{g} \mathrm{g}^{-1} \mathrm{FW}\right)\end{array}$} \\
\hline & & $\mathrm{A}_{260 / 280}$ & $\mathrm{~A}_{260 / 230}$ & & \\
\hline \multirow{3}{*}{ Song et al. [8] } & Leaf & $0.90-1.30$ & $0.75-1.20$ & 6.6 & 64 \\
\hline & Bud & $0.90-1.00$ & $0.80-1.00$ & 1.4 & 36 \\
\hline & Pulp & -- & - &.- & - \\
\hline \multirow{3}{*}{ Modified protocol } & Leaf & $2.00-2.40$ & $2.00-2.30$ & 8.0 & $300-500$ \\
\hline & Bud & $2.00-2.40$ & $2.00-2.30$ & 8.3 & $400-700$ \\
\hline & Pulp & $2.00-2.11$ & $2.00-2.31$ & 8.0 & 23 \\
\hline
\end{tabular}

and irreversibly denature the proteins [13]. The PVPP concentration was increased to improve exclusive combination with polyphenols to form complexes through hydrogen bonding $[14,15]$. Therefore, both the browning and contamination (phenolic compounds) were reduced by adding PVPP and high concentrations of $\beta$-mercaptoethanol to the extraction buffer.

Although proteinase $\mathrm{K}$ is an efficient and non-specific enzyme for digesting cellular proteins, samples treated with proteinase $\mathrm{K}$ buffer did not result in a higher $\mathrm{A}_{260 / 230}$ ratio as expected. Thus, it was not used in our study.

Extraction with phenol:chloroform:isoamyl alcohol was repeated three times, resulting in an efficient separation of the RNA aqueous phase from proteins and polysaccharides [11, 16] and avoiding a major loss of total RNA as discard [8]. During homogenization in a phenol-containing solution and centrifugation, the sample separated into three phases: a lower organic phase, a middle white phase that contained denatured proteins and genomic DNA, and an upper aqueous phase that contained RNA. The aqueous phase was recovered, after each extraction, by careful pipetting. Unavoidable trace amounts of insoluble interphase material and/or chloroform were transferred through filaments formed between the interphases and the tip. Therefore, extra centrifugations due to the extra phenol:chloroform:isoamyl alcohol extractions were necessary to discard the insoluble material and the residual chloroform. Besides, these centrifugation steps at higher $g$-force $(20,000 \mathrm{~g})$ are reported to considerably improve the purity and quantity of the RNA sample [11]. The reporting very low RNA yield may have been due to chloroform present in the liquid prior to $\mathrm{LiCl}$ precipitation.

Then a chloroform:isoamyl alcohol extraction was added to eliminate remaining phenolic compounds and further reduce contaminants. Additionally, the use of $100 \%$ isopropanol facilitated the effective precipitation of RNA and rendered it more stable in the precipitated form [17]. With this modified method, yield and total RNA quality in loquat leaves, buds and fruit pulp were significantly improved in comparison with that used by Song et al. [8] (table I). In fact, Liu et al. [18] used an improved CTAB method described by Asif et al. [7] for banana RNA extraction instead of the method described previously by themselves for loquat [8], suggesting that their own method had some kind of problems, as we verified. Whereas yield from previous protocols did not exceed $70 \mu \mathrm{g} \mathrm{g}^{-1} \mathrm{FW}$, we consistently obtained yields higher than $300 \mu \mathrm{g} \mathrm{g}^{-1} \mathrm{FW}$ from loquat leaves and buds (table I). All samples tested showed $\mathrm{A}_{260 / 230}$ ratios greater than $2.00,1.8$ being

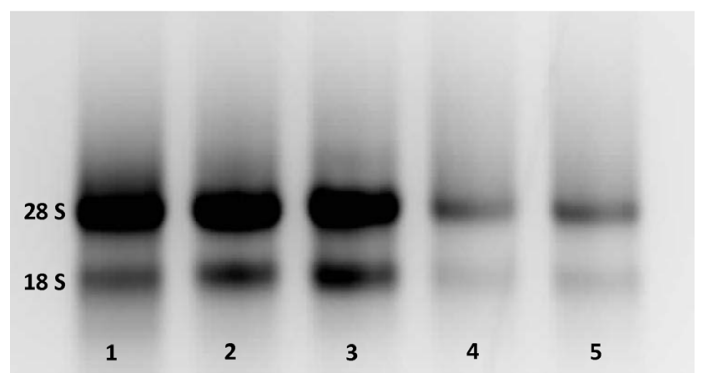

Figure 1. The denaturing agarose gel electrophoresis of total RNA extracted by our modified protocol (Lane 1,2 and 3) and the Song et al. method (Lane 4 and 5) from leaf (Lane 1 and 4), bud (Lane 2 and 5), and fruit pulp (Lane 3). The 18S and 28S rRNA bands are shown.

the minimum acceptable value [7,19]. In contrast, those tested ratios reported by Song et al. [8] were lower than 1.2 (table I). Results indicated that our samples were only slightly contaminated by polysaccharides or polyphenolic compounds (table I). The $\mathrm{A}_{260 / 280}$ ratio ranged 2.00-2.40, indicating no protein contamination [18] whereas those reported by Song et al. [8] did not exceed 0.90-1.00 (table I). It is important to note that for low amounts of isolated RNA, both the $\mathrm{A}_{260 / 280}$ ratio and the $\mathrm{A}_{260 / 230}$ ratio should be very close to 2.0. Ratio values under 1.0 indicate contamination with chaotropic salts or remaining phenolic compounds or proteins in the RNA solution.

As shown for RNA isolation from different fruit tree species tissues, in our study of loquat tissues RNA was not degraded as observed when visualizing the ribosomal RNA of the samples in a denatured $1.5 \%$ agarose gel with RNA stained with ethidium bromide. In all samples, two bands, which corresponded to $28 \mathrm{~S}$ and $18 \mathrm{~S}$ rRNA, were distinguishable (figure 1). This indicates the high quality of RNA, as reported by Ausubel et al. [20] Nevertheless, research has suggested that conventional methods, like spectrophotometry and electrophoresis analysis, are often not sensitive or specific enough for single-stranded RNA, and they are also susceptible to contaminants [21,22].

In order to properly estimate the integrity of our RNA samples, we also used the Agilent 2100 Bioanalyzer. This is a bio-analytical device which combines microfluidics, microcapillary electrophoresis and fluorescence detection which not only provides the basis for an automated, user-independent and reproducible evaluation of RNA but also allows for the 


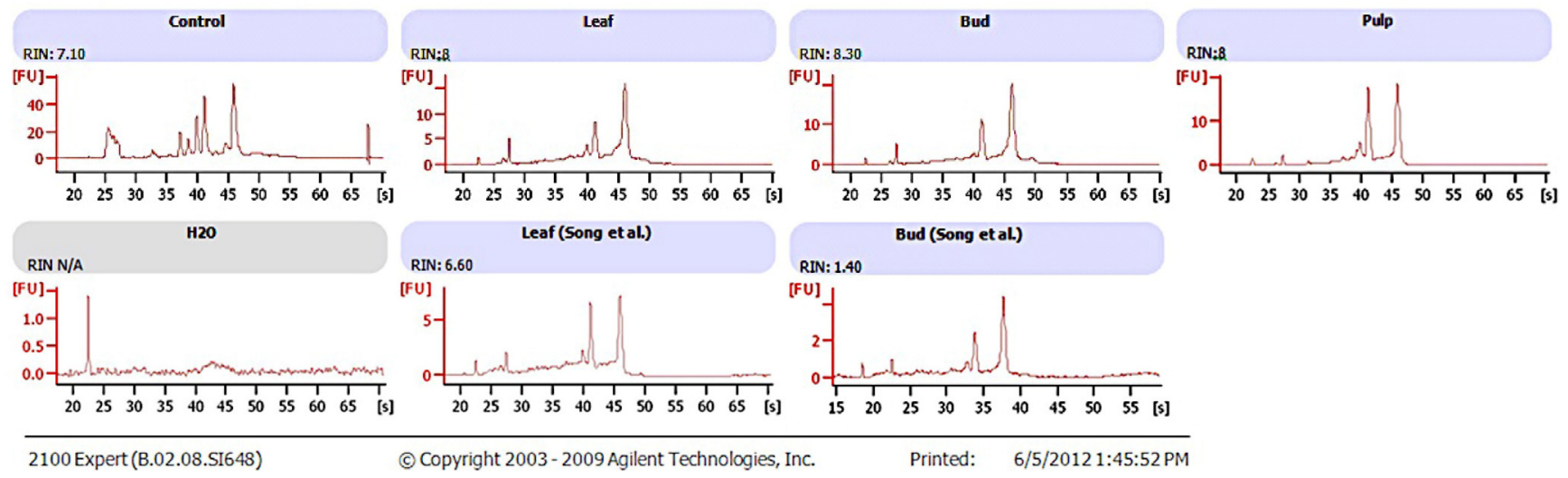

Figure 2. Bioanalyzer results of total RNA extracted using our modified protocol and the Song et al. method. Extractions were made from leaf, bud and pulp tissues as indicated and run on an Agilent 2100 Bioanalyzer.

calculation of an RNA Integrity Number (RIN). It allows for the classification of total RNA isolated, based on a numbering system from 1 to 10 , with 1 being the most degraded and 10 being the most intact RNA. The RIN values should definitely be higher than 7.5-8.0 to be accepted [20]. Our procedure allowed for RIN values higher than 8.0 and higher than the 6.6 obtained by Song et al. [8], for loquat (table I, figure 2), and by Asif et al. [7], for banana. This modified method to isolate high quality RNA may prove to be effective for other recalcitrant species.

\section{Conclusion}

The protocol developed and described in this paper allowed for large quantities of high quality RNA to be obtained from loquat leaves, buds and fruit pulp. This RNA was of sufficient quality to be suitable for downstream techniques such as RT-qPCR, and thus, the modifications carried out here greatly enhance the method described by Song et al. [8].

Acknowledgements. The authors thank Dr. Pérez-Amador and Dr. Vera for their experienced advice, Dr. Alfaro for reviewing the manuscript, and Dr. Westall (UPV) for editing the manuscript.

\section{References}

[1] De Vries S., Hoge H., Bisseling T., Isolation of total and polysomal RNA from plant tissues, in: Gelvin S. B., Schilperoort R. A., Verma D. P. S. (Eds.), Plant Molecular Biology Manual, Kluwer Academic Publishers, Dordrecht, 1993, pp. 1-13.

[2] Ferreres F., Gomes D., Valentao P., Goncalves R., Pio R., Chagas E.A., Seabra Andrade P.B., Improved loquat (Eriobotrya japonica Lindl.) cultivars: variation of phenolics and antioxidative potential, Food Chem. 114 (2009) 1019-1027.

[3] Liu Y.X., Yang X.H., Lin S.Q., Hu G.B., Liu C.M., An improved procedure for nuclear DNA isolation from Eriobotrya plants and its application, J. Fruit Sci. 22 (2005) 182-185.

[4] Biedrzycka E., Amarowicz R., Diet and health: apple polyphenols as antioxidants, Food Rev. Inter. 2 (2008) 235-251.
[5] Ferreira D., Guyot S., Marnet N., Delgadillo I., Renard C.M.G.C., Coimbra M.A., Composition of phenolics compounds in a Portuguese pear (Pyrus comunis L. var. S. Bartomeu) and changes after sun-drying, J. Agric. Food Chem. 50 (2002) 4537-4544.

[6] Wang S.X., Hunter W., Plant A., Isolation and purification of functional total RNA from woody branches and needles of Sitka and white spruce, Biotechniques 28 (2000) 292-296.

[7] Asif H., Dhawan P., Nath P., A simple procedure for the isolation of high quality RNA from ripening banana fruit, Plant Mol. Biol. Rep. 18 (2000) 109-115.

[8] Song H., Liu Y., Hu G., Qin Y., Lin S., An improved method for total RNA isolation from recalcitrant loquat (Eriobotrya japonica Lindl.) buds, Pakistan J. Bot. 43 (2011) 1163-1171.

[9] Chang S., Puryear J., Cairney J., A simple method for isolating RNA from pine trees, Plant Mol. Biol. Rep. 11 (1993) 113-116.

[10] Salzman R.A., Fujita T., Zhu-Salzman K., Hasegawa P.M., Bressan R.A., An improved RNA isolation method for plant tissues containing high levels of phenolic compounds or carbohydrates, Plant Mol. Biol. Rep. 17 (1999) 11-17.

[11] Zeng Y., Yang T., RNA isolation from viscous samples rich in polyphenols and polysaccharides, Plant Mol. Biol. Rep. 20 (2002) 415-417.

[12] Jones C.S., Iannetta P.P.M., Woodhead M., Davies H.V., McNicol R.J., Taylor M.A., The isolation of RNA from raspberry (Rubus idaeus) fruit, Mol. Biotech. 8 (1997) 219-221.

[13] Wang L., Stegemann J.P., Extraction of high quality RNA from polysaccharide matrices using cetyltrimethylammonium bromide, Biomaterials 31 (2010) 1612-1618.

[14] Hu C.G., Honda C., Kita M., Zhang Z., Tsuda T., Moriguchi T., A simple protocol for RNA isolation from fruit trees containing high levels of polysaccharides and polyphenol compounds, Plant Mol. Biol. Rep. 20 (2002) 69a-69g.

[15] Kolosova N., Miller B., Ralph S., Ellis B.E., Douglas C., Ritland K., Bohlman J., Isolation of high quality RNA from gymnosperm and angiosperm trees, Biotechniques 36 (2004) 821-824.

[16] Sambrook J., Russell D.W., Molecular cloning: A laboratory manual (3rd ed.), Cold Spring Harbour Laboratory Press, Cold Spring Harbour, New York, USA, 2001.

[17] González-Mendoza D., Quiroz A., Zapata O. An improved method for the isolation of total RNA from Avicenia germinans leaves, Verlag der Zeitschrift für Naturforschung 63 (2008) 124-126. 
[18] Liu Y., Song H., Liu Z., Hu G., Lin S., Molecular characterization of loquat EjAP1 gene in relation to flowering, Plant Growth Regul. 70 (2013) 287-296.

[19] Becker C., Hammerle-Fickinger A., Riedmaier I., Pfaffl M.W., mRNA and microRNA quality control for RT-qPCR analysis, Methods 50 (2010) 237-243.

[20] Ausubel F.M., Brent R., Kingston R.E., Moore D.D., Smith J.A., Seidman J.G., Struhl K., Current protocols in Molecular Biology, John Wiley and Sons, New York, USA, 1997.
[21] Imbeaud S., Graudens E., Boulanger V., Barlet X., Zaborski P., Eveno E., Mueller O., Schoeder A., Auffray C., Towards standardization of RNA quality assessment using user-independent classifiers of microcapillary electrophoresis traces, Nucleic Acids Research 33 (2005) 1-12.

[22] Schroeder A., Mueller O., Stocker S., Salowsky R., Leiber M., Gassmann M., Lightfoot S., Menzel W., Granzow M., Ragg T., The RIN: an RNA integrity number for assigning integrity values to RNA measurements, BCM Mol. Biol. 7 (2006) 3.

Cite this article as: Amparo Martínez-Fuentes, Carlos Mesejo, Manuel Agustí, Carmina Reig. Toward a more efficient isolation of total RNA from loquat (Eriobotrya japonica Lindl.) tissues. Fruits 70 (2015) 47-51. 